\title{
WOOD DENSITY OF TREES IN BLACK WATER FLOODPLAINS OF RIO JAÚ NATIONAL PARK, AMAZONIA, BRAZIL
}

\author{
Pia PAROLIN ${ }^{1}$, Martin WORBES ${ }^{1}$
}

\begin{abstract}
The Jaú National Park is the largest protected forested area in the world. The Vitória Amazônica Foundation is working towards understanding its ecosystem, to which this paper contributes. Wood density was analysed in 27 common tree species growing in the blackwater floodplains of the Rio Jaú, an affluent of the Rio Negro (Amazonia, Brazil). Wood was sampled with an increment borer. Mean wood density of the analysed species ranged from 0.35 to $0.87 \mathrm{~g} \mathrm{~cm}^{-3}$. The mean of all sampled species was $0.67 \mathrm{~g} \mathrm{~cm}^{-3}$ (st. dev. 0.13 ). Lowest density was found for Hevea spruceana with $0.32 \mathrm{~g} \mathrm{~cm}^{-3}$ and highest for Crudia amazonica with $0.9 \mathrm{~g} \mathrm{~cm}^{-3}$.
\end{abstract}

Key-words: Wood specific gravity, wood density, increment rings, blackwater floodplain forest, igapó, Rio Jaú, Central Amazonia.

Densidade de Madeira de Árvores nas Áreas Inundáveis do Parque Nacional do Jaú, Amazônia, Brasil

RESUMO - O Parque Nacional do Jaú é a maior área protegida do mundo completamente coberta por floresta. Este trabalho contribui para o conhecimento deste ecossistema, em colaboração com a Fundação Vitória Amazônica. A densidade da madeira de 27 espécies de árvores comuns nas áreas inundáveis do Rio Jaú, um afluente do Rio Negro, foi determinada com o método não destrutivo do trado. A densidade média das espécies analisadas variou entre $0.35 \mathrm{e} 0.87 \mathrm{~g} \mathrm{~cm}^{-3}$. A média de todas as espécies foi de $0.67 \mathrm{~g} \mathrm{~cm}^{-3}$ (st. dev. 0.13). A menor densidade medida foi em Hevea spruceana com $0.32 \mathrm{~g} \mathrm{~cm}^{-3}$ e a maior em Crudia amazonica com $0.9 \mathrm{~g} \mathrm{~cm}^{-3}$.

Palavras-chave: Densidade de madeira, aneis de incremento, floresta inundavel, igapó, Rio Jaú, Amazônia central.

\section{INTRODUCTION}

The Jaú National Park is the largest protected forested area in the world. The Rio Jaú is an affluent of the Rio Negro (Amazonia, Brazil). The whole Jaú River basin was declared a National Park. In cooperation with the Vitória Amazônica Foundation / Manaus, inventories of non-flooded terra firme forest and flooded igapó forest were performed in 1994 (Ferreira, 1997) as first steps towards an understanding of the ecosystem. This paper contributes with a study on wood density of common tree species of the blackwater inundation forests (igapó).
Trees have characteristic wood densities. In tropical terra firme forests, density ranges from 0.05 to 1.08 $\mathrm{g} \mathrm{cm}^{-3}$ (Rueda \& Williamson, 1992). For trees of Central Amazonian inundation forests, which are subjected to periodical flooding lasting up to 7 months a year (Junk, 1989), the range of wood density lies between 0.26 and $0.94 \mathrm{~g} \mathrm{~cm}^{-3}$ (Worbes, 1989). When looking at white and black water systems separately, the density range in white water forests (Ilha da Marchantaria, Central Amazonia) lies between 0.24 and $0.72 \mathrm{~g} \mathrm{~cm}^{-3}$ (Martius, 1992), or between 0.20 and $0.80 \mathrm{~g} \mathrm{~cm}^{-3}$ (Parolin et al. 1998,

\footnotetext{
${ }^{1}$ Max-Planck Institute for Limnology, Tropical Ecology, P.O. Box 165, 24302 Plön, Germany
} 
Parolin \& Ferreira, 1998). To date not many species have been examined and few data have been published on blackwater forests specifically. Wood density is one of the most important quality features. The study gives a first orientation of the potential for timber use.

\section{MATERIAL AND METHODS}

For wood density determination, samples were taken from some of the most common tree species in the Jaú National Park. Species were chosen based on floristic inventories made by Leandro V. Ferreira (unpublished data, and Ferreira \& Stohlgren, 1999). The species were determined in the field by Leandro V. Ferreira and José Ramos at the Amazon Research Institute in Manaus (INPA).

Only adult, healthy individuals were chosen. Twenty seven species were sampled with a total of 114 individuals. One to twelve trees of each chosen species were sampled at 1.30 $m$ above the ground. In a few cases in which the trees were still standing in the water (Eschweilera tenuifolia), the sample had to be taken higher on the stem. Trees with buttresses were sampled above the buttress. In the case of Swartzia polyphylla, which has high buttresses instead of a compact stem, samples were taken at $130 \mathrm{~cm}$ from the buttresses. Since most trees grow on slopes, samples were always taken on the part of the stem not facing the water. In all cases, diameter at breast height (dbh) and position in the flood gradient (determined by the mark of the year's high water level on the tree stem) were recorded.

Instead of using the usual destructive method of wood density determination, in which the tree has to be cut to take wood samples, the method of Howe (1974) and Whitmore (1973) was used, taking wood samples with an increment borer at breast height. This method is very fast and hardly affects the tree. Density of the samples was determined by calculating the relation of fresh volume to dry weight. The volume of the core was calculated by measuring the fresh sample with a vernier caliper: $\pi r^{2} h$, where $r$ is the radius of the core $=0.25 \mathrm{~cm}$, and $\mathrm{h}$ the length of the sample. Each core was cut into pieces of $1.5 \mathrm{~cm}$ length after removing the bark, so that h was $1.5 \mathrm{~cm}$. Dry weight was measured after oven drying for four days at $105^{\circ} \mathrm{C}$.

Wood increment was measured exclusively in 9 individuals of 6 species which grew on a particular azonal, very rocky site on Praia das Inscrições, close to the confluence of Rio Jaú and Rio Negro. This site was chosen because extreme low annual increments were expected. For the determination of annual increments, whole stem sections were analysed and tree rings were counted.

\section{RESULTS AND DISCUSSION}

Among the species analysed in this study, mean density ranged from 0.35 to $0.87 \mathrm{~g} \mathrm{~cm}^{-3}$ (Table 1). Absolute lowest density was found for Hevea spruceana with $0.32 \mathrm{~g} \mathrm{~cm}^{-3}$ (mean $0.35 \mathrm{~g} \mathrm{~cm}^{-3}$ ) and highest for Crudia amazonica with $0.9 \mathrm{~g} \mathrm{~cm}^{-3}$ (mean 0.87 
$\mathrm{g} \mathrm{cm}^{-3}$ ). The mean of all sampled spe- $\mathrm{g} \mathrm{cm}^{-3}$ in Tabebuia barbata and 0.90 cies was $0.67 \mathrm{~g} \mathrm{~cm}^{-3}$ (st. dev. 0.13). $\mathrm{g} \mathrm{cm}^{-3}$ in Licania heteromorpha Worbes found higher values up to 0.92 (unpubl. data).

Table 1. Species mean wood density, density range, standard deviation (sd), number of sampled individuals $(\mathrm{n})$, and inundation period resulting from typical position in the flood gradient for 27 species in blackwater flooded forests of Rio Jaú National Park. Inundation period long $=4$ to 7 months, short $=0$ to 3 months.

\begin{tabular}{|c|c|c|c|c|c|}
\hline Species & $\begin{array}{l}\text { Density range } \\
\text { [g cm-3] }\end{array}$ & $\begin{array}{l}\text { Mean density } \\
{[\mathrm{g} \mathrm{cm}-3]}\end{array}$ & sd & $\mathrm{n}$ & Inundation period \\
\hline Hevea spruceana & $0.32-0.38$ & 0.35 & 0.02 & 6 & long \\
\hline Simaba orinocense & $0.36-0.48$ & 0.42 & 0.05 & 3 & long \\
\hline Macrolobium acaciifolium & $0.36-0.59$ & 0.44 & 0.09 & 4 & long \\
\hline Leopoldinia pulchra & $0.35-0.54$ & 0.48 & 0.09 & 3 & short \\
\hline Maprounea guianensis & $0.58-0.59$ & 0.58 & 0.01 & 4 & short \\
\hline Nectandra am azonum & $0.48-0.66$ & 0.58 & 0.06 & 6 & short \\
\hline Laetia suaveolens & & 0.59 & & 1 & short \\
\hline Ormosia excelsa & $0.59-0.64$ & 0.62 & 0.02 & 3 & long \\
\hline Swartzia laevicarpa & $0.54-0.69$ & 0.62 & 0.04 & 6 & short \\
\hline Suartzia polyphylla & $0.56-0.68$ & 0.62 & 0.04 & 7 & short \\
\hline Pentaclethra macroloba & & 0.64 & & 1 & short \\
\hline Parkia discolor & $0.62-0.69$ & 0.64 & 0.03 & 4 & short \\
\hline Mabea nitida & $0.61-0.81$ & 0.7 & 0.09 & 4 & short \\
\hline Buchenavia ochnopnuma & $0.59-0.83$ & 0.71 & 0.08 & 4 & long \\
\hline Sclerolobium hypoleucum & $0.71-0.73$ & 0.71 & 0.01 & 3 & short \\
\hline Acosmium nitens & $0.67-0.77$ & 0.72 & 0.05 & 2 & short \\
\hline Pouteria elegans & $0.52-0.83$ & 0.72 & 0.11 & 8 & short \\
\hline Aldina latifolia & $0.67-0.81$ & 0.74 & 0.04 & 12 & short \\
\hline Eschweilera tenuifolia & $0.71-0.79$ & 0.75 & 0.03 & 5 & long \\
\hline Alibertia sp. & $0.71-0.80$ & 0.76 & 0.03 & 5 & long \\
\hline Licania apetala & & 0.76 & & 1 & long \\
\hline Tabebuia barbata & $0.7-0.84$ & 0.78 & 0.05 & 6 & long \\
\hline Couepia paraensis & $0.76-0.85$ & 0.8 & 0.03 & 4 & long \\
\hline Campsiandra comosa & $0.8-0.83$ & 0.81 & 0.01 & 2 & long \\
\hline Amanoa oblongifolia & & 0.83 & & 1 & long \\
\hline Burdachia duckei & $0.79-0.87$ & 0.84 & 0.03 & 3 & long \\
\hline Crudia amazonica & $0.84-0.9$ & 0.87 & 0.02 & 6 & long \\
\hline
\end{tabular}




\section{Density determination with increment borer}

The determination of mean density with an increment borer is not usual but has been proven to show no significant differences to the conventional method of determination from whole stem samples (Whitmore, 1973). In this study (Tab. 3), comparison with other authors who analysed the same species (common in black and/or white water) shows that differences between the methods are included in the typical density range.

\section{Comparison of wood density in black and white water forests}

In an earlier study (Parolin \& Ferreira, 1998), mean wood density of common species of white water forests of Central Amazonia was determined with the same method as described above. Density range in white water forests was found to be higher than in black water forests, ranging from 0.24 to $0.80 \mathrm{~g} \mathrm{~cm}^{-3}$, with a mean of 0.48 (st. dev. 0.16). A similar mean density of $0.495 \mathrm{~g} \mathrm{~cm}^{-3}$ was found by Martius (1992) for these forests.

The fact that density is lower in white water forests is due to the occurrence of species with low density, which typically are pioneers, such as the genera Solanum, Pseudobombax, Cecropia. In black water systems these genera are absent, and the distinction of pioneers and non-pioneers is not as clear as in white water systems. There is evidence (Ferreira, pers. comm.) that the usual categories do not apply to this system. In fact, in clearings in the black water forests of the Rio Jaú

Table 3. Comparison of wood densities $\left(\mathrm{g} \mathrm{cm}^{-3}\right)$ in different studies determined with different methods: Parolin $=$ increment borer, other studies $=$ whole stem section.

\begin{tabular}{|c|c|c|c|c|c|c|c|c|c|c|c|}
\hline \multirow[b]{2}{*}{ Species } & \multicolumn{3}{|c|}{ Parolin \& Wortes (present study) } & \multicolumn{2}{|c|}{ Worbes 1989} & \multirow[b]{2}{*}{$\mathrm{N}$} & \multicolumn{2}{|c|}{ Worbes et al. 1992} & \multirow{2}{*}{$\begin{array}{l}\text { Martius } 1992 \\
\text { mean } \pm \text { sd }\end{array}$} & \multirow[b]{2}{*}{$\mathrm{N}$} & \multirow[b]{2}{*}{$\begin{array}{l}\text { floodplain } \\
\text { system }\end{array}$} \\
\hline & mean $\pm s d$ & range & $\mathrm{N}$ & mean & range & & mean $\pm s d$ & $\mathrm{~N}$ & & & \\
\hline Cecropia latiloba & $0.36 \pm 0.01$ & $0.36-0.37$ & 2 & & & & 0.48 & 1 & $0.37 \pm 0.06$ & 7 & white \\
\hline Crateva benthami & $0.5 \pm 0.05$ & $0.44-0.57$ & 6 & 0.42 & $0.39-0.45$ & 2 & $0.42 \pm 0.03$ & $?$ & $0.43 \pm 0.03$ & 4 & white \\
\hline Eschweilera tenuifolia & $0.75 \pm 0.03$ & $0.71-0.79$ & 5 & 0.71 & & 1 & 0.75 & 1 & & & black \\
\hline Laetia suaveolens & 0.59 & & 1 & 0.74 & & 1 & & & & & black \\
\hline Macrolobium acairfolium & $0.4 \pm 0.04$ & $0.37-0.44$ & 2 & 0.43 & & 1 & 0.48 & 1 & & & white \\
\hline Nectandra arnazonum & $0.49 \pm 0.03$ & $0.47-0.54$ & 7 & 0.47 & & 1 & 0.47 & 1 & & & white \\
\hline Pseudobombax munguba & $0.27 \pm 0.03$ & $0.24-0.32$ & 4 & 0.26 & & 1 & $0.25 \pm 0.02$ & $?$ & $0.23 \pm 0.07$ & 5 & white \\
\hline Salix humboldtiana & $0.39 \pm 0.01$ & $0.37-0.41$ & 7 & & & & 0.42 & 1 & & & white \\
\hline Skertzia laevicarpa & $0.62 \pm 0.04$ & $0.54-0.69$ & 6 & 0.59 & $0.56-0.64$ & 3 & & & & & black \\
\hline Suertzia polyphylla & $0.62 \pm 0.04$ & $0.56-0.68$ & 7 & 0.56 & & 1 & & & & & black \\
\hline Tabebuia barbata & $0.67 \pm 0.02$ & $0.64-0.68$ & 3 & 0.72 & $0.53-0.92$ & 15 & $0.71 \pm 0.1$ & $?$ & & & white \\
\hline Vitex cymosa & $0.57 \pm 0.06$ & $0.45-0.65$ & 9 & 0.59 & & 1 & 0.59 & 1 & $0.48 \pm 0.01$ & 4 & white \\
\hline
\end{tabular}


it appears that the seedlings, saplings and young trees are of the same species which dominate the old growth, and no particular colonizers could be found. Further studies about this would be interesting.

It is particularly interesting to look at the few species which occur in tion of climatic variations (inundation) affect growth (Howe, 1974).

Wood density shows variations depending on environmental factors. Dry season in the tropics, cold season in temperate regions, or inundation in periodically inundated forests such as the Central Amazonian floodplains

Table 4. Comparison of mean wood density and density range between individuals occurring in white water (Ilha da Marchantaria) and black water (Rio Jaú) floodplains.

\section{Mean wood density Density range}

\begin{tabular}{lcccc} 
Species & Ilha da March. & Rio Jaú & Ilha da March. & Rio Jaú \\
\hline Crudia amazonica & 0.80 & 0.87 & $0.79-0.80$ & $0.84-0.90$ \\
Macrolobium acaciifolium & 0.40 & 0.44 & $0.37-0.44$ & $0.36-0.59$ \\
Nectandra amazonum & 0.49 & 0.58 & $0.47-0.54$ & $0.48-0.66$ \\
Tabebuia barbata & 0.67 & 0.78 & $0.64-0.68$ & $0.70-0.84$ \\
\hline
\end{tabular}

both systems (Tab, 4). Correlations have not been tested statistically, but a trend can be seen which shows that individuals growing in white water have a lower mean density and density range than individuals of the same species growing in black water.

Explanations for the differences in wood density in the two systems are probably complex but poorly investigated. Little is known about the sampled tree species, and tree growth in flooded forests is still poorly understood (Klinge et al., 1983; Furch, 1984; Worbes, 1983, 1986; Junk, 1989). Nutrient supply is higher in white water floodplains: these rivers carry a high sediment load and thus enrich the soils (Irion et al., 1983). Soil quality, water supply, light incidence, and the occurrence and dura- cause a strong impact on growth and thus on wood density. Whitmore (1973) compared wood density of Costa Rican balsa (Ochroma lagopus) from a variety of ecologically distinct areas and found characteristic differences between individuals depending on the climatic and hydrological conditions of the site.

\section{Position in the flood gradient}

The position of a tree in the flood gradient is proportional to the length of inundation (Junk, 1989) and to the period of unfavourable growth conditions. According to Ferreira (unpublished data), species distribution varies along the gradient, some species being confined to shorter, others to longer inundated areas. Few species 
occur along the whole gradient.

Preliminary analysis of wood density in relation to inundation duration shows a trend in which species subjected to longer inundation periods have higher wood density (Fig. 1). The most tolerant species, which occur at the lowest levels and get flooded for the longest time each year, have the

\section{Wood increments}

Wood increments of the trees from the particular rocky site on Praia das Inscrições were between 1.56 and $3.14 \mathrm{~mm}$ year- $^{-1}$ (Tab. 2). The annual increments of the trees from the azonal rocky site on Praia das Inscrições were compared to increments measured at other blackwater sites. In comparison

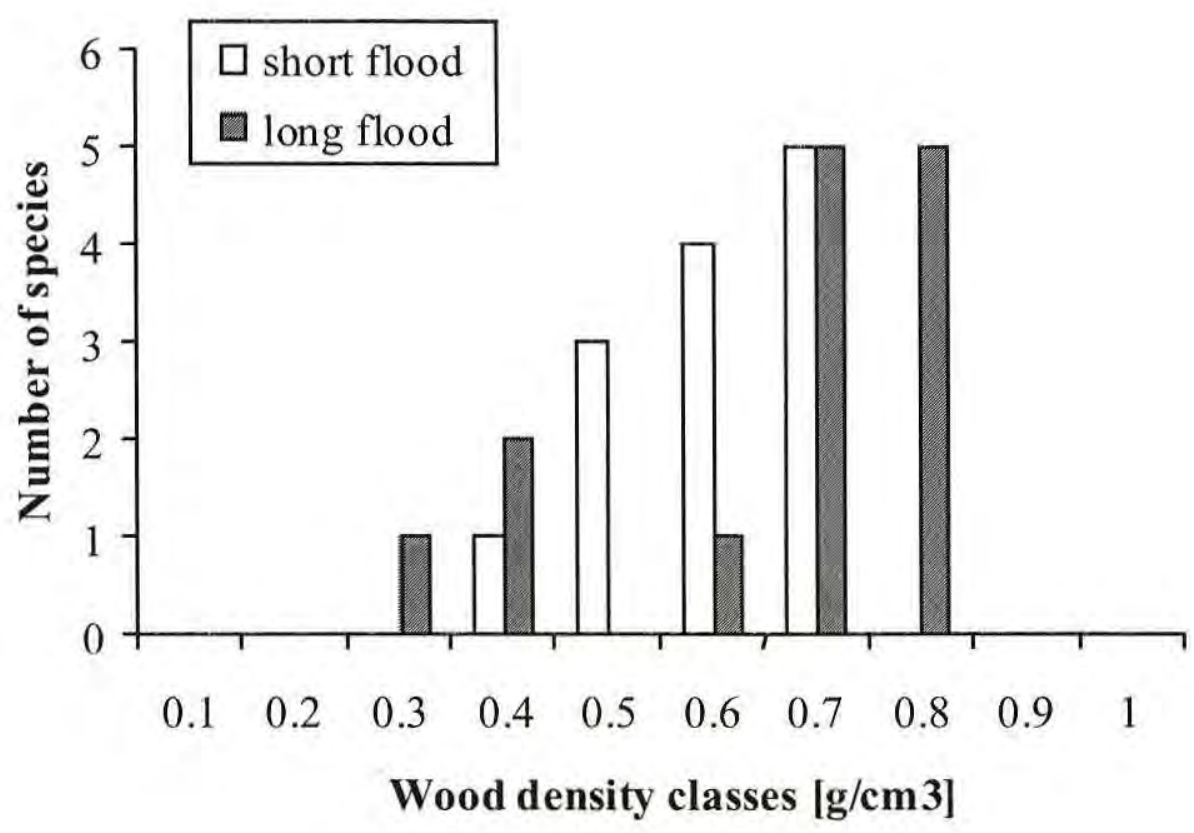

Figure 1. Wood density distribution of 27 species inundated for long (4-7 months) and short (0-3 months) periods.

highest density values (Crudia amazonica, Burdachia duckei, Amanoa oblongifolia). On the other hand, at the lowest levels the species with the lowest values (Hevea spruceana, Simaba orinocense, Macrolobium acaciifolium) occur also. with whitewater floodplains, the annual increments were very low at Praia das Inscrições. In the várzea of the Ilha da Marchantaria, increments of 4.4 to $10 \mathrm{~mm}$ year ${ }^{-1}$ were measured in nonpioneer species, and in fast-growing pioneer species increments were 15 
Table 2 -Wood increment of trees on an azonal, very rocky surface at Praia das Inscrições, close to the confluence of the Rio Jaú and the Rio Negro.

\begin{tabular}{lccccc}
\hline Species & $\begin{array}{c}\text { Mean density } \\
{[\mathrm{g} \mathrm{cm}-3]}\end{array}$ & $\begin{array}{c}\text { Tree dbh } \\
{[\mathrm{cm}]}\end{array}$ & $\begin{array}{c}\text { Tree height } \\
{[\mathrm{m}]}\end{array}$ & $\begin{array}{c}\text { Number } \\
\text { of rings }\end{array}$ & $\begin{array}{c}\text { hcrement } \\
{[\mathrm{mm} \text { year-1] }}\end{array}$ \\
\hline Acosmium nitens & 0.78 & 6.4 & 3.5 & 11 & 2.91 \\
Buchenavia ochnopnuma & 0.61 & 5.4 & 3.5 & 15 & 1.80 \\
Elvasia sp. & 0.71 & 6.4 & 4.5 & 16 & 2.00 \\
Licania ape tala & 0.78 & 6.9 & 4 & 11 & 3.14 \\
Licania apetala & 0.59 & 5.4 & 5 & 13 & 2.08 \\
Maprounea guianensis & 0.48 & 5.5 & 4 & 15 & 1.83 \\
Tabebuia barbata & 0.76 & 5.6 & 3.5 & 15 & 1.87 \\
Tabebuia barbata & 0.76 & 5.6 & 4.5 & 18 & 1.56 \\
Tabebuia barbata & 0.78 & 5.5 & 4 & 16 & 1.72 \\
\hline
\end{tabular}

$\mathrm{mm}$ year $^{-1}$ (Cecropia latiloba) and $21.4 \mathrm{~mm}$ year $^{-1}$ (Senna reticulata) (Parolin \& Ferreira, 1998). This is the main explanation. Growth rates and wood densities are negatively correlated (Worbes 1989).

\section{Further studies}

The present study was only preliminary, with a low sample size. Probably more than 240 species occur in the floodplains of Rio Jaú National Park (Ferreira, unpublished data). The trends found here indicate directions for further work. The main future objectives should be to increase sample size of each species and species number from both black and white water systems of flooded forests in Central Amazonia. Further analysis of the correlations between wood density and position in the flood gradient (= inundation duration) would be interesting, as well as the analysis of density gradients along the stem cross section and the comparison in pioneers and non-pioneers (Wiemann \&
Williamson, 1989).

\section{ACKNOWLEDGMENTS}

We wish to thank Leandro V. Ferreira, the INPA/Max-Planck Project (Manaus / Plön) and the Fundação Vitória Amazônica (FVA, Manaus).

\section{Literature cited}

Ferreira, L.V. 1997. Effects of the duration of flooding on species richness and floristic composition in three hectares in the Jaú National Park in floodplain forests in Central Amazonia. Biodiv and Cons., 6:13531363.

Ferreira, L.V.; Stohlgren, T.J. 1999. Effects of river level fluctuation on plant species richness, diversity, and distribution in a floodplain forest in Central Amazonia. Oecologia, 120:582-587.

Furch, B. 1984. Investigations concerning the inundation tolerance of trees in the várzea and the igapo - Leaf chlorophyll contents. Biogeographica, 19:77-83.

Howe, J.P. 1974. Relationship of climate to the specific gravity of four Costa Rican hardwoods - an exploratory study. Wood and Fiber, 5(64):347-352. 
Irion, G.; Adis, J.; Junk, W.J.; Wunderlich, F. 1983. Sedimentological studies of the Ilha de Marchantaria in the Solimôes / Amazon River near Manaus. Amazoniana, 8:1-18.

Junk, W.J. 1989. Flood tolerance and tree distribution in Central Amazonian floodplains. In: Nielsen, L.B.; Nielsen, I.C.; Balslev, H. (Eds.) Tropical forests: botanical dynamics, speciation and diversity. Academic Press, London. pp. 47-64.

Klinge, H.; Furch, K.; Harms, E.; Revilla, J. 1983. Foliar nutrient levels of native tree species from Central Amazonia. Amazoniana, 8:19-46.

Martius, C. 1992. Density, humidity, and nitrogen content of dominant wood species of floodplain forests (várzea) in Amazonia. Holz als Roh- und Werkstoff, 50:300-303.

Parolin P., Ferreira L.V. \& Junk W.J. (1998): Central Amazonian floodplains: effect of two water types on the wood density of trees. Verh. Internat. Verein. Limnol. 26(3):1106-1112.

Parolin, P.; Ferreira, L.V. 1998. Are there differences in specific wood gravities between trees in várzea and igapó (Central Amazonia)? Ecotropica, 4:25-32.
Rueda, R.; Williamson, G.B. 1992. Radial and vertical wood specific gravity in Ochroma pyramidale (Cav. ex Lam.) Urb. (Bombacaceae). Biotropica, 24:512-518.

Whitmore, J.L. 1973. Wood density variation in Costa Rican balsa. Wood Science, 5:223-229.

Wiemann, M.C.; Williamson, G.B. 1989. Wood specific gradients in tropical dry and montane rain forest trees. Amer. J. Bot., 76(6):924-928.

Worbes, M. 1983. Vegetationskundliche Untersuchungen zweier Überschwemmungswälder in Zentralamazonien - vorläufige Ergebnisse. Amazoniana, 8:47-66.

Worbes, M. 1986. Lebensbedingungen und Holzwachstum in zentralamazonischen Überschwemmungswäldern. Scripta Geobotanica, 17:112.

Worbes, M. 1989. Growth rings, increment and age of trees in inundation forests, savannas and a mountain forest in the Neotropics. IAWA Bulletin 10(2):109-122. 